\title{
IMPROVING PERFORMANCE OF LEAD-ACID BATTERIES THROUGH CARBON LEAD HYBRID ELECTRODES
}

\author{
VAN MEN TRUONG*1, NGOC BICH DUONG ${ }^{2}$, TRAN VAN DIEN ${ }^{1}$ AND HUYNH THANH \\ $\mathrm{BANH}^{1}$
}

${ }^{1}$ School of Engineering and Technology, Tra Vinh University, 126 Nguyen Thien Thanh Street, Ward 5, Tra Vinh 87000, Vietnam. ${ }^{2}$ School of Agriculture and Aquaculture, Tra Vinh University, 126 Nguyen Thien Thanh Street, Ward 5, Tra Vinh 87000, Vietnam.

*Corresponding author: tvmen@tvu.edu.vn

Submitted final draft: 18 June $2020 \quad$ Accepted: 25 June 2020

http://doi.org/10.46754/jssm.2021.04.008

\begin{abstract}
This paper presents the study of the addition of carbon materials to negative electrodes to upgrade the performance of lead-acid batteries through avoiding sulfation and getting super capacitance effects due to their high specific surface area. Two kinds of carbon materials including carbon fibre paper and activated carbon cloth with high electrical conductivity and porosity are selected in the experiments. The required hydrophilicity of the carbon materials is pretreated and checked through the surface contact angle measurement before added. The surface morphology of carbon materials, negative electrodes are also observed using Scanning Electron Microscope. The results show that the performance of the carbon-added battery cells is improved. The initial capacity and specific energy of the tested battery cells with the carbon cloth addition are about $15 \%$ higher than those of battery cells without the carbon addition. Moreover, the lead sulphate crystal size formed on the negative electrode surfaces of the carbon added batteries are smaller than that on the negative electrode surfaces of the conventional batteries, revealing that carbon addition can improve the battery lifespan.
\end{abstract}

Keywords: Lead-acid battery, battery performance, carbon lead hybrid, carbon material.

\section{Introduction}

Lead-acid batteries are the most used battery in automobile, transportation and telecommunication industries. They basically consist of sponge lead plates (negative electrodes), separator (insulation material), lead dioxide plates (positive electrode), and the electrolyte (sulfuric acid). The chemical reactions take place at anode and cathode during the charge/discharge processes as follows (Zimáková et al., 2015) (note that the upper arrow represents the direction of the reaction during discharging and the lower arrow while charging):

$$
\begin{aligned}
& \text { At positive electrode: } \mathrm{PbO}_{2(s)}+4 \mathrm{H}_{(a q)}^{+}+\mathrm{SO}_{4(a q)}^{2-}+2 e^{-} \rightleftarrows \mathrm{PdSO}_{4(s)}+2 \mathrm{H}_{2} \mathrm{O}_{(L)} \\
& \text { At negative electrode: } \mathrm{Pb}_{(s)}+\mathrm{SO}_{4(a q)}^{2-} \rightleftarrows \mathrm{PdSO}_{4(s)}+2 e^{-} \\
& \text {Overall reaction: } \mathrm{Pb}_{(s)}+\mathrm{PbO}_{2(s)}+\mathrm{H}_{2} \mathrm{SO}_{4(L)} \rightleftarrows 2 \mathrm{PdSO}_{4(s)}+2 \mathrm{H}_{2} \mathrm{O}_{(L)}
\end{aligned}
$$

With advanced technology, to provide the power capability and adequate service-life in advanced systems, lead-acid batteries should work as effectively as possible under high-rate, partial-state of charge/discharge (HRPSoC) conditions that quickly cause the accumulation of lead sulfate $\left(\mathrm{PbSO}_{4}\right)$ on the negative plates which can't be converted successfully back to spongy lead during the charging process, leading to battery failure (Lam et al., 2004). In recent years, many researchers are interested in improving performance and cycling life of leadacid batteries in order to meet the demands of modern applications. 
Many attempts have been carried out, and it is found that adding carbon to leadacid electrodes during paste preparation in a variety of forms, including activated carbon, carbon black, graphite and carbon nanotubes, can enhance both performance and lifespan of the batteries. In particular, Shiomi et al. (1997) investigated the benefits of carbon added to the negative active material (NAM). They proposed that the advantages were caused by a conductive network of carbon particles formed on $\mathrm{PbSO}_{4}$ crystals leading to the improvement of cycle life performance. Their opinion was later agreed by Ohmae et al (Ohmae et al., 2003). They also suggested that highly conductive carbon should be used to retard the sulfation process. Pavlov et al. (Pavlov et al., 2009) discovered that the electrochemical reaction of lead ions occurs simultaneously on both surfaces of $\mathrm{Pb}$ and carbon particles during the cycling of cells. A parallel electrochemical mechanism was also proposed based on their experiments. Xiang's group (Xiang et al., 2013) has pointed out that the roles of carbon additives to negative plates under HRPSoC duty can be summarized from three aspects: (i) increasing the porosity and active surface area of NAM due to formation of a new porous-skeleton builder; (ii) facilitating electrolyte diffusion from the surface to the inner of plates; (iii) sharing excess charge and discharge current with negative plates. Sugumaran et al. (2015) demonstrated that the incorporation of discrete carbon nanotubes (dCNT) was useful not only in negative plates but also in positive plates. Cycle life tests of the batteries increased more than $60 \%$ as the negative plates were accompanied by $\mathrm{dCNT}$ while it was significantly improved by $500 \%$ in the case of both electrodes added. The dCNT/ $\mathrm{H}_{\mathrm{ad}}$ overcharge reaction mechanism was also proposed to explain their observation. A similar observation when adding carbon materials to anode and cathode electrodes was also reported by Lang et al. (2018). Furthermore, the impact of different types and concentrations of carbon materials have been studied as additives in lead-acid batteries. Cycle life under HRPSoC operation was enhanced as the optimized content of graphite and black carbon was the same amount of 2wt.\% (Boden et al., 2010). In addition, the maximum cycle number was achieved at low concentration of graphite (near 1 1.5 wt.\%) added to negative plates as observed by some other researchers (Bača et al., 2011; Soria et al., 2005). Blecua et al. (2017) investigated the influences of different carbon materials on lead-acid batteries used for micro-hybrid vehicles. They reported that carbon materials with big particle size were able to improve cycle life and charge acceptance while carbon black with small particle size $(<1$ $\mu \mathrm{m})$ may increase water consumption and fail to prolong cycle life. In addition, the effects of specific surface area (SSA) and morphology of different carbon materials added to the cathode electrode of lead-acid battery were explored by $\mathrm{Hu}$ et al. (2019). Carbon materials with larger SSA and smaller carbon particle size are beneficial for enhancing battery performance. The former can enlarge the electrochemical active surface of the active material while the latter is more effectively dispersed within the active materials. Besides, Yin et al. (2018) also demonstrated that high reversibility of the anode and low hydrogen evolution of lead-acid battery can be achieved by grafting lead on the anode $\mathrm{C} / \mathrm{Pd}$ composite. They concluded that the main roles of $\mathrm{C} / \mathrm{Pd}$ composite in the anode includes maintaining a solid anode structure with high specific surface area and enhancing charge acceptance. In their latter work (Yin et al., 2019), the optimized composition of $\mathrm{C} / \mathrm{Pd}$ was also obtained. The results showed that the cycle life of the battery cell with the addition of optimized $\mathrm{C} / \mathrm{Pd}$ composite to the negative plate is about 11 times longer than that of the blank one under HRPSoC. Carbon material addition can be designed to provide super capacitance effects. Particularly, Lam et al. (Lam et al., 2006; Lam et al., 2007) have developed the ultra-battery with a conventional $\mathrm{PbO}_{2}$ positive plate and a negative plate consisting of two parts: half of it is a sponge lead material and the other half is a carbon electrode. Their results showed that the performance of the ultra-battery increased by $50 \%$ and its cycle life is significantly improved 
compared to the conventional lead-acid battery. The carbon electrode in the ultra-battery design acts as an asymmetric supercapacitor which is able to provide and rapidly absorb charge during HRPSoC operations. The application of the ultra-battery design for a fuel cell hybrid vehicle was then numerically investigated (Huang et al., 2016). By applying a lithium battery and the ultra-battery as auxiliary power sources in the fuel cell hybrid vehicle module, the simulation results showed that the power output curves of the ultra-battery and lithium battery are extremely similar, while the cost of ultrabatteries is competitive with the lithium battery.

Carbon fiber papers or carbon clothes are currently the most common materials used to make gas diffusion layers (GDL) in fuel or biofuel cells (Zhang et al., 2002; Liu et al., 2009; Zhang et al., 2017). In addition, it is also preferred for use in supercapacitors as electrodes (Shang et al., 2017; Bavio et al., 2017; Wang et al., 2016; Li et al., 2017) because they possess the advantages of good conductivity, porous form, high specific surface area, corrosion resistance, stability, and moderate cost. In the last two decades, the advantages of using carbon papers or carbon clothes instead of using metallic alloy in lithium-ion batteries have been discovered by many research groups ( $\mathrm{Su}$ et al., 2012; Isaev et al., 2003; Arbizzani et al., 2005; Arbizzani et al., 2006). As carbon papers were used as a substrate-current collector, it enhanced not only constant capacity but also cycle life due to the flexible property of carbon materials which provides good contact with the cathode surface, offering electron pathways during lithiation/delithiation (Arbizzani et al., 2005; Arbizzani et al., 2006). When the microporous carbon paper was inserted between cathode and separator, it decreased the internal charge transfer resistance and captured the migrating polysulphides during electrochemical reactions.

From earlier studies, it is obvious that the addition of carbon materials can enhance the performance and prolong the cycle life of lead-acid batteries. However, mixing carbon powder with active electrode materials will make manufacturing processes of lead-acid batteries more complex. Therefore, in this work, a simple approach without elaborate synthesis of composites and surface chemistry modification is studied for improving the capacity and cycle life of conventional lead-acid batteries. Highly porous and electrically conductive carbon materials under the form of fiber paper or cloth are prepared and directly added in parallel to the negative plates of an assembled $2 \mathrm{~V}$ lead-acid cell with two positive plates and three negative plates that are separated by absorbed glass-mat (AGM). The carbon interlayer is expected to provide the electrically conductive network on the negative electrode surface and the super capacitance effect which not only acts to limit the formation of hard sulfation inside the cell but also increases its charge acceptability. The ratio of the surface area of carbon sheets to negative plates is $1: 2$ or $1: 1$. The contact angle measurement, SEM, and chronopotentiometry are employed for the characterization of carbon materials, carbon lead hybrid electrodes and constant current discharge in this investigation.

\section{Materials and Methods}

\section{Preparation and Characterization of the Added Carbon Materials}

Carbon fiber papers and activated carbon clothes (produced by CeTech, Taiwan) with thicknesses of $0.60 \mathrm{~mm}$ and $0.65 \mathrm{~mm}$ were used in this study as shown in Figure 1(a) and (b), respectively. The specific surface area and porosity analysis for the prepared samples were characterized by $\mathrm{N}_{2}$-adsorption/desorption isotherms at $77 \mathrm{~K}$ (ASAP 2020, Micromeritics, USA). The pore volume and pore size were calculated according to the method of BJH (Barrett Johner Halenda). The characteristics of the carbon paper and activated carbon cloth are summarized in Table 1. The results show that the specific surface area and pore volume of the activated carbon cloth are larger than those of the carbon fiber paper. The estimated average pore size for the activated carbon cloth (115.036 $\AA$ ) is also much greater than that of the carbon fiber paper (20.927 $\AA$ ). 

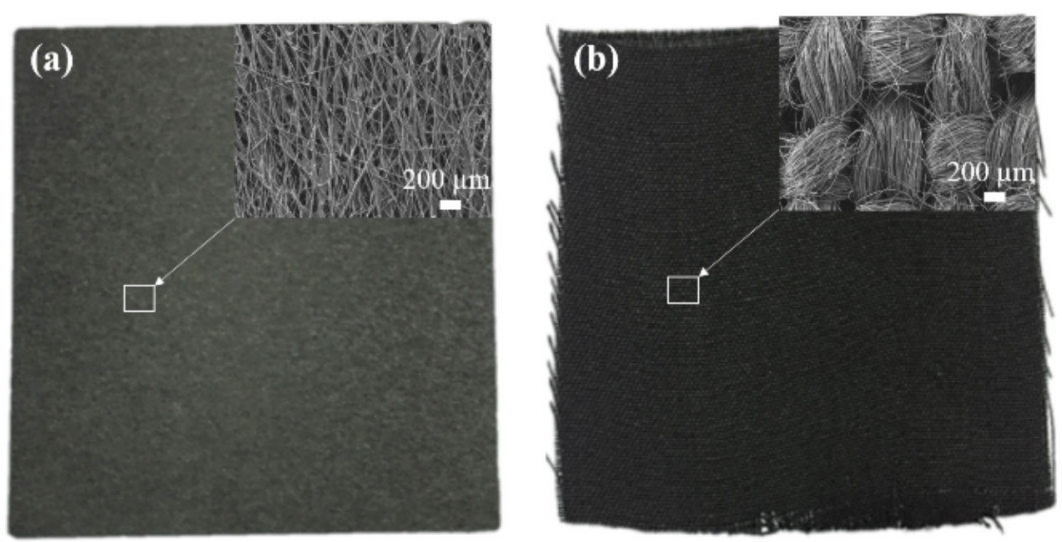

Figure 1: Carbon materials: (a) Carbon fiber paper and (b) Activated carbon cloth

Table 1: Specific characteristics of carbon materials used in this study

\begin{tabular}{ccccc}
\hline Carbon type & $\begin{array}{c}\text { BET surface } \\
\text { area }\left(\mathbf{m}^{2} / \mathbf{g}\right)\end{array}$ & $\begin{array}{c}\text { Pore area } \\
\left(\mathbf{m}^{2} / \mathbf{g}\right)\end{array}$ & $\begin{array}{c}\text { Pore volume } \\
\left(\mathbf{c m}^{3} / \mathbf{g}\right)\end{array}$ & $\begin{array}{c}\text { Average pore } \\
\text { size }(\mathbf{\AA})\end{array}$ \\
\hline Carbon fiber paper & 1.4773 & 1.2845 & 0.000672 & 20.927 \\
\hline Activated carbon cloth & 1.6006 & 1.4695 & 0.004226 & 115.036 \\
\hline
\end{tabular}

\section{Preparation of the Negative and Positive Plates}

In this study, the positive plates and negative plates mainly made of lead dioxide and sponge lead, respectively, were all produced by Taiwan KUNG LONG batteries industrial CO., LTD. The areal loadings of the negative plate, positive plate, and AGM separator are 1.06, 1.09, and $0.064 \mathrm{~g} \mathrm{~cm}^{-2}$, respectively. The sizes of the negative and positive electrodes are $75 \mathrm{~mm} \times$ $37 \mathrm{~mm} \times 1.8 \mathrm{~mm}$ and $75 \mathrm{~mm} \times 37 \mathrm{~mm} \times 2.0$ $\mathrm{mm}$, (height $\times$ width $\times$ thickness), respectively. Absorbent Glass Mats (AGMs) with a size of 80 $\mathrm{mm} \times 40 \mathrm{~mm} \times 3.0 \mathrm{~mm}$ were used to separate the positive plates and negative plates. The electrolyte was $\mathrm{H}_{2} \mathrm{SO}_{4}$ with a density of $1.28 \mathrm{~g} /$ $\mathrm{cm}^{3}$ (Yang et al., 2017) used during all tests. The real battery cell is presented in Figure 2 .

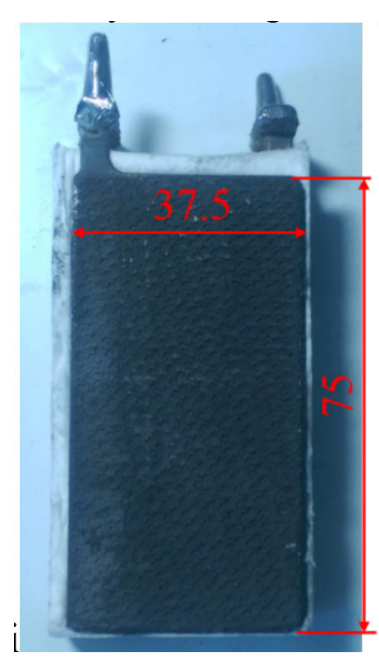

Figure 2: The actual battery cell used in this work 


\section{Design of the Tested Lead-Acid Cells}

The influence of the addition of carbon fiber paper and activated carbon cloth to negative plates on battery performance was investigated in $2 \mathrm{~V}$ test cells. The schematic of the test cells is shown in Figure 3. In each $2 \mathrm{~V}$ test cell, three negative plates were assembled with two positive plates and AGM separators with a thickness of $3.0 \mathrm{~mm}$. The prepared carbon papers or cloth were manually introduced to the cell. In particular, three negative plates electrically connected by bridge weld were interlaced with two positive plates electrically connected in the same manner. After that, Absorbent Glass Mat (AGM) and carbon fiber paper or cloth, prepared to the proper sizes, were inserted into the gap between the negative and positive plates, where the carbon fiber was contacted with the negative plates as shown in Figure 3. The ratio of the surface area of the carbon material to the negative plate was $1: 2$ or $1: 1(50 \%$ or $100 \%$, defined as insertion ratio). The designed cell was placed inside a plastic container provided by the supplier (Taiwan KUNG LONG batteries industrial CO., LTD). Subsequently, the electrolyte $\left(\mathrm{H}_{2} \mathrm{SO}_{4}\right)$ was introduced to the cell from the top. After that, the cell was sealed with a top cover and sealing glue to form a sealed lead-acid battery. The positive and negative terminals were exposed outside the top cover for charge and discharge processes. There was a safety valve on the cover designed to release any excess pressure if the battery is overcharged. As a result, the loss of $\mathrm{H}_{2} \mathrm{SO}_{4}$ in the sealed lead acid battery cell can be significantly diminished. For comparison, a $2 \mathrm{~V}$ cell consisting of the same negative and positive plates without carbon sheet addition was also produced.

\section{Capacity Test}

For this test, fully charged battery cells were discharged to the final voltage of $1.6 \mathrm{~V}$ (cut-off voltage) at a constant current of $0.5 \mathrm{~A}$. The cells were then charged for $12 \mathrm{~h}$ at a constant voltage of $2.5 \mathrm{~V}$ with a current limit of $0.25 \mathrm{~A}$. These cells were subsequently cycled. All the tests are carried out at room temperature $\left(\sim 25^{\circ} \mathrm{C}\right)$. The capacity and specific energy of the tested battery cells were calculated from the following Eqs. (4) and (5).

$$
\begin{aligned}
& C=I \times t \\
& E_{S}=\frac{1}{m} \int_{t_{0}}^{t} \quad U(t) \times I \times d t
\end{aligned}
$$

where: $\mathrm{C}$ is the capacity (Ah); $\mathrm{E}_{\mathrm{s}}$ is the specific energy $(\mathrm{Wh} / \mathrm{kg}) ; \mathrm{I}, \mathrm{U}(\mathrm{t})$, $\mathrm{t}$, and $\mathrm{m}$ are the discharge current (A), discharge voltage, discharge time (h), and mass of battery cell (kg).

\section{Results and Discussion}

Carbon fiber paper and activated carbon cloth were required to have hydrophilic characteristics in order to make $\mathrm{H}_{2} \mathrm{SO}_{4}$ solution or water easily penetrate these layers. However, by using Optical Contact Angle Meter Model 100SB, the original carbon fiber papers and activated carbon cloth were hydrophobic with the surface contact angle of $129.99^{\circ}$ and $124.60^{\circ}$, respectively, as

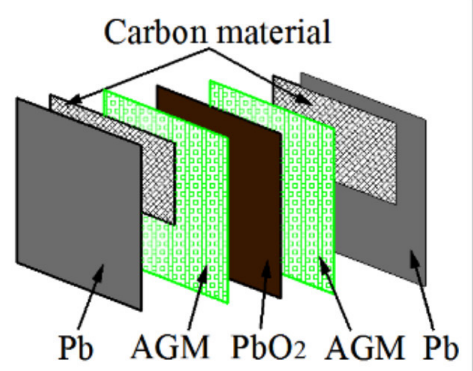

(a)

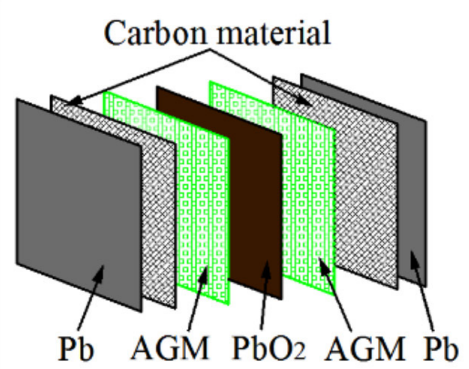

(b)

Figure 3: Schematic of the tested lead-acid cell: (a) 50\%; (b) 100\% 
depicted in Figures 4(a) and (b). To form the hydrophilic functional group $(\mathrm{COOH})$, they were immersed in the mixture of concentrated acids $\left(\mathrm{H}_{2} \mathrm{SO}_{4}: \mathrm{HNO}_{3}=3: 1\right)$ for 10 minutes with sonication to produce carboxylic acid group (COOH) (Zhang et al., 2008). The contact angle measurement of the treated carbon materials was then observed. As shown in Figures 4(a1) and (b1), after modification, a droplet of contact angle measurement was immediately absorbed once it reached the carbon paper or carbon cloth surfaces. Water was evenly laid on the surfaces and it is defined as the contact angle $0^{\circ}$. In other words, the hydrophilicity of the modified carbon materials meets the requirement for this investigation.

Figure 5 shows the discharge curves of the batteries with and without adding carbon materials at a constant discharge current of 0.5 A. It is observed that the discharge time of the battery cells with carbon fiber paper or activated carbon cloth is longer than that without carbon addition, indicating that the performance of the carbon-inserted battery cells is improved. The initial capacity and specific energy of the tested battery cells were also calculated and presented in Table 2. With carbon insertion, the initial capacity and specific energy of the tested batteries increase. It is expected that the presence of the carbon pieces could have two main benefits. The first is increasing the charge acceptance during charging, due to the supper capacitance effect of the inserted carbon materials (Lam et al., 2007; Huang et al., 2016; Smith et al., 2002). In other words, with carbon fiber addition, a super capacitor is formed based on one leaddioxide positive plate and one carbon-based negative plate. As a result, during the charging process, a certain amount of charge will be electrostatically stored on the carbon plates and release this additional charge in the discharge process, improving the cell capacity. The second benefit is enhancing electron conductivity on the negative electrode surfaces due to a conductivity network formed by the carbon plates (Moseley et al., 2006). During discharging, the partial transfer of electrons generated on the negative electrode surface can be implemented through the carbon plate, helping the sponge lead react with $\mathrm{HSO}_{4}$ - to evenly form $\mathrm{PdSO}_{4}$ on the negative surface. Conversely, in the charging process, the external electrons are partially transferred from the carbon plate to the negative plate, making a better dissolution of $\mathrm{PdSO}_{4}$. Accordingly, the reversibility of the charging and discharging processes is improved. The results also show that the larger an area of carbon materials was added, the better battery performance was achieved. This makes sense, because more charge will be stored on the larger carbon surface area. In general, a higher insertion ratio is also beneficial for both conductive network
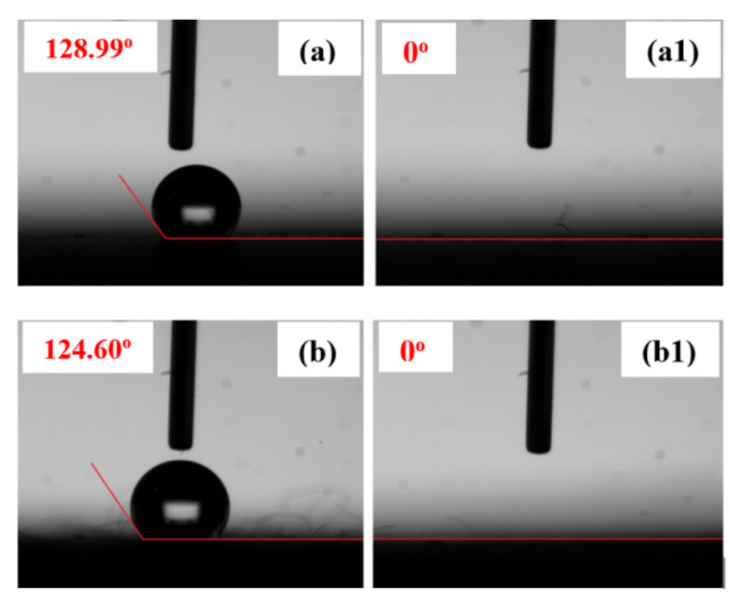

Figure 4: Contact angle measurement of carbon fiber paper: (a) before modification; (a1) after modification and of activated carbon cloth: (b) before modification; (b1) after modification 
formation and supercapacitance effect, leading to better battery performance. The highest improvement of the specific energy of the tested battery cell with the insertion ratio of $1: 1$ of the activated carbon cloth is around $15 \%$ compared to the conventional battery cell. Furthermore, the addition of activated carbon cloth exhibits better initial capacity and specific energy than that of carbon fiber paper. This could be due to activated carbon cloth possessing higher flexibility and larger specific surface area (as presented in Table 1) compared with the carbon fiber paper. As a result, the first property will make better contact between the carbon cloth surface and negative electrode surface, which provide a better conductive network for electrons transfer during chemical reactions while the second one will provide large gravimetric capacitance and hence energy storage density (Zhang et al., 2013; Ji et al., 2014). The reported improvement of lead-acid battery performance using different carbon materials as additives is summarized in Table 3. It can be seen that our lead-acid battery cell with carbon-lead hybrid negative electrodes exhibits a comparable initial capacity, as compared with the previously reported results in lead-acid battery researches, suggesting that the carbon fiber insertion to the negative electrodes can be used for improving the performance of conventional lead-acid batteries.

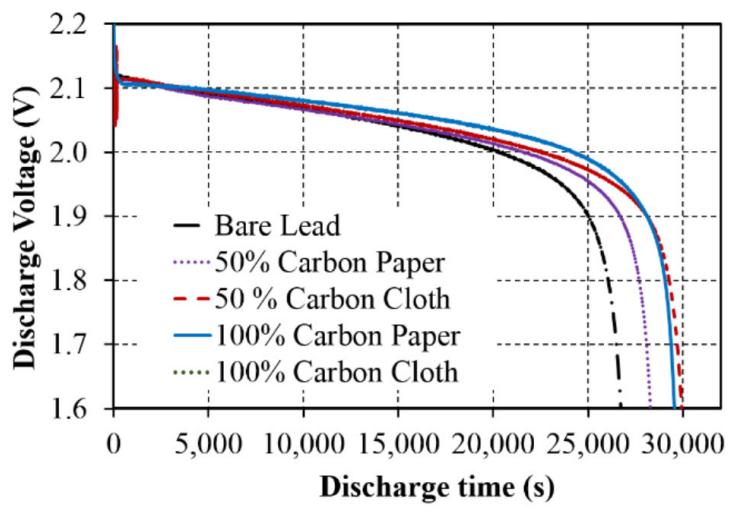

Figure 5: Discharge curves of the tested battery cells

Table 2: Initial capacity and specific energy

\begin{tabular}{cccccc}
\hline Tested Cell & Bare lead & $\begin{array}{c}\mathbf{5 0 \%} \text { carbon } \\
\text { paper } \\
\text { inserted }\end{array}$ & $\begin{array}{c}\mathbf{5 0 \%} \\
\text { carbon } \\
\text { cloth } \\
\text { inserted }\end{array}$ & $\begin{array}{c}\mathbf{1 0 0 \%} \\
\text { carbon } \\
\text { paper } \\
\text { inserted }\end{array}$ & $\begin{array}{c}\mathbf{1 0 0 \%} \\
\text { carbon } \\
\text { cloth } \\
\text { inserted }\end{array}$ \\
\hline $\begin{array}{c}\text { Initial Capacity (Ah) } \\
\text { Specific energy }\end{array}$ & $3.76 \pm 0.11$ & $3.98 \pm 0.13$ & $4.25 \pm 0.10$ & $4.21 \pm 0.14$ & $4.32 \pm 0.13$ \\
Wh/kg & $32.03 \pm 0.11$ & $33.90 \pm 0.12$ & 36.16 & $36.02 \pm 0.14$ & $36.88 \pm 0.12$ \\
$\begin{array}{c}\text { Improved capacity } \\
(\%)\end{array}$ & - & 5.9 & 13.2 & 12.0 & 14.9 \\
$\begin{array}{c}\text { Improved specific } \\
\text { energy (\%) }\end{array}$ & - & 5.8 & 12.9 & 12.5 & 15.1 \\
\hline
\end{tabular}


Table 3: Reported improvement of lead-acid batteries using different carbon materials as additives

\begin{tabular}{ccc}
\hline Discharge rate & $\begin{array}{c}\text { Improved percentage of initial } \\
\text { capacity }(\%)\end{array}$ & Reference \\
\hline $0.05 \mathrm{C}$ & 23.5 & (Saravanan et al., 2012) \\
$0.5 \mathrm{C}$ & 3.5 & (Hong et al., 2014) \\
$0.5 \mathrm{C}$ & 10.7 & (Kumar et al., 2014) \\
$1 \mathrm{C}$ & 26.7 & (Zou et al., 2014) \\
$0.1 \mathrm{C}$ & 5.5 & (Saravanan et al., 2015) \\
$0.1 \mathrm{C}$ & 19.9 & (Lang et al., 2018) \\
$0.1 \mathrm{C}$ & 14.9 & (Yin et al., 2019) \\
$1.8 \mathrm{C}$ & 11.5 & (Hu et al., 2019) \\
$0.125 \mathrm{C}$ & 14.9 & This work \\
\hline
\end{tabular}

To observe the lead sulfate crystals on the negative electrodes after discharging, the negative electrodes were rinsed in several baths of deionized water and scanned using SEM (Hitachi model S-3400N). The SEM images of different negative electrode surfaces are shown in Figure 6. It can be observed that the size of the lead sulfate crystals on the carbon added negative electrode surfaces are smaller than those on the bare negative electrode surfaces. This is because the added carbon materials can facilitate the formation of small isolated $\mathrm{PbSO}_{4}$ particles which are easy to dissolve and restrict $\mathrm{PbSO}_{4}$ crystal growth (Shiomi et al., 1997). The results indicate that the lifespan of battery cells with carbon materials inserted could be improved compared to the original battery cells since the larger lead sulfate crystals are harder and cannot be completely converted back to sponge lead during the charge process (Sugumaran et al., 2015; Pavlov et al., 2012; Murali et al., 2017). In addition, the lead crystals formed on the negative electrode with carbon cloth addition have a smaller size than those formed on the negative electrode with carbon paper addition. This could be due to the higher flexibility of carbon cloth than carbon paper, which provides better contact between the carbon cloth and the negative electrode surface, leading to better electron conduction during the chemical reactions. This observation is consistent with the initial capacity results in which the better capacity of the lead-acid batteries with added carbon cloth is achieved compared to the leadacid batteries with added carbon fiber paper. The surface area and porosity measurements for the negative electrodes will be conducted in future work.

\section{Conclusion}

A simple method to boost the performance of lead-acid batteries has been proposed and experimentally studied in this work. The results show that the lead-acid batteries exhibit improved performance when carbon paper or carbon cloth is added to the negative electrode surfaces. The initial capacity of the battery with $100 \%$ carbon cloth insertion increases by $15 \%$ compared to the original lead-acid counterpart. Additionally, morphology analyses of negative electrode surfaces indicate that the cycle life of batteries with carbon lead hybrid electrodes could be prolonged. Further experiments are ongoing to demonstrate the newly designed battery works effectively under different working conditions, and will be published in the future.

\section{Acknowledgements}

We are thankful to CeTech Co Ltd., Taiwan for supplying carbon materials and Taiwan KUNG LONG batteries industrial CO., LTD for providing lead-acid batteries. 

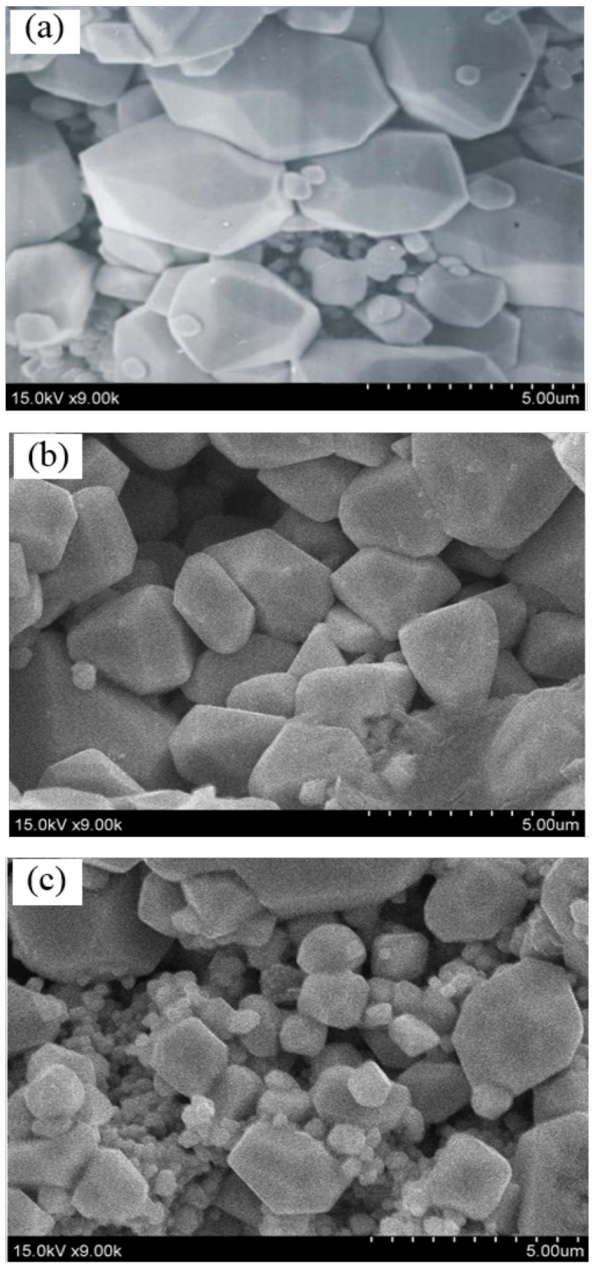

Figure 6: SEM images of negative electrode surface after discharge to $1.6 \mathrm{~V}$ : (a) without carbon material; (b) with carbon paper; (c) with carbon cloth

\section{References}

Arbizzani, C., Beninati, S., Lazzari, M., \& Mastragostino, M. (2005). Carbon paper as three-dimensional conducting substrate for tin anodes in lithium-ion batteries. Journal of Power Sources, 141(1), 149-155.

Arbizzani, C., Beninati, S., Lazzari, M., \& Mastragostino, M. (2006). On the lithiation-delithiation of tin and tin-based intermetallic compounds on carbon paper current collector-substrate. Journal of Power Sources, 158(1), 635-640.

Bača, P., Micka, K., Křivík, P., Tonar, K., \& Tošer, P. (2011). Study of the influence of carbon on the negative lead-acid battery electrodes. Journal of Power Sources, 196(8), 3988-3992.

Bavio, M. A., Acosta, G. G., Kessler, T., \& Visintin, A. (2017). Flexible symmetric and asymmetric supercapacitors based in nanocomposites of carbon cloth/polyaniline - carbon nanotubes. Energy, 130, 22-28.

Blecua, M., Fatas, E., Ocon, P., Valenciano, J., de la Fuente, F., \& Trinidad, F. (2017). Influences of carbon materials and lignosulfonates in the negative active material of lead-acid batteries for 
microhybrid vehicles. Journal of Energy Storage, 11, 55-63.

Boden, D. P., Loosemore, D. V., Spence, M. A., \& Wojcinski, T. D. (2010). Optimization studies of carbon additives to negative active material for the purpose of extending the life of VRLA batteries in high-rate partial-state-of-charge operation. Journal of Power Sources, 195(14), 4470-4493.

Hong, B., Jiang, L., Xue, H., Liu, F., Jia, M., Li, J., \& Liu, Y. (2014). Characterization of nano-lead-doped active carbon and its application in lead-acid battery. Journal of Power Sources, 270, 332-341.

Hu, H.-Y., Xie, N., Wang, C., Wu, F., Pan, M., Li, H.-F., Wu, P., Wang, X.-D., Zeng, Z., Deng, S., Wu, M. H., Vinodgopal, K., \& Dai, G.P. (2019). Enhancing the performance of motive power lead-acid batteries by high surface area carbon black additives. Applied Sciences, 9(1), 186.

Huang, P.-H., Kuo, J.-K., \& Huang, C.-Y. (2016). A new application of the UltraBattery to hybrid fuel cell vehicles. International Journal of Energy Research, 40(2), 146159.

Isaev, I., Salitra, G., Soffer, A., Cohen, Y. S., Aurbach, D., \& Fischer, J. (2003). A new approach for the preparation of anodes for Li-ion batteries based on activated hard carbon cloth with pore design. Journal of Power Sources, 119-121, 28-33.

Ji, H., Zhao, X., Qiao, Z., Jung, J., Zhu, Y., Lu, Y., Zhang, L. L., MacDonald, A. H., \& Ruoff, R. S. (2014). Capacitance of carbonbased electrical double-layer capacitors. Nature Communications, 5(1), 3317.

Kumar, S. M., Ambalavanan, S., \& Mayavan, S. (2014). Effect of graphene and carbon nanotubes on the negative active materials of lead acid batteries operating under highrate partial-state-of-charge operation. $R S C$ Advances, 4(69), 36517-36521.

Lam, L. T., Haigh, N. P., Phyland, C. G., \& Urban, A. J. (2004). Failure mode of valve- regulated lead-acid batteries under high-rate partial-state-of-charge operation. Journal of Power Sources, 133(1), 126-134.

Lam, L. T., \& Louey, R. (2006). Development of ultra-battery for hybrid-electric vehicle applications. Journal of Power Sources, 158(2), 1140-1148.

Lam, L. T., Louey, R., Haigh, N. P., Lim, O. V., Vella, D. G., Phyland, C. G., Vu, L. H., Furukawa, J., Takada, T., Monma, D., \& Kano, T. (2007). VRLA Ultrabattery for high-rate partial-state-of-charge operation. Journal of Power Sources, 174(1), 16-29.

Lang, X., Li, Y., Cai, K., Li, L., Zhang, Q., \& $\mathrm{Wu}, H$. (2018). Preparation of bipolar lead-carbon electrode and study on its electrochemical performance. Ionics, 24(3), 935-941.

Li, Q., Guo, X., Zhang, Y., Zhang, W., Ge, C., Zhao, L., Wang, X., Zhang, H., Chen, J., Wang, Z., \& Sun, L. (2017). Porous graphene paper for supercapacitor applications. Journal of Materials Science \& Technology, 33(8), 793-799.

Liu, C.-H., Ko, T.-H., Kuo, W.-S., Chou, H.-K., Chang, H.-W., \& Liao, Y.-K. (2009). Effect of carbon fiber cloth with different structure on the performance of low temperature proton exchange membrane fuel cells. Journal of Power Sources, 186(2), 450-454.

Moseley, P. T., Nelson, R. F., \& Hollenkamp, A. F. (2006). The role of carbon in valveregulated lead-acid battery technology. Journal of Power Sources, 157(1), 3-10.

Murali, L. G., Srinivas, K., Murthy, K. S., \& Jagadish, M. (2017). Recovery process of sulphated flooded lead-acid batteries with organic polymer compounds as activator. International Journal of Science and Research, 6(10), 388-397.

Ohmae, T., Hayashi, T., \& Inoue, N. (2003). Development of 36-V valve-regulated leadacid battery. Journal of Power Sources, 116, 105-109. 
Pavlov, D., \& Nikolov, P. (2012). Lead-carbon electrode with inhibitor of sulfation for lead-acid batteries operating in the HRPSoC duty. Journal of the Electrochemical Society, 159(8), A1215-A1225.

Pavlov, D., Rogachev, T., Nikolov, P., \& Petkova, G. (2009). Mechanism of action of electrochemically active carbons on the processes that take place at the negative plates of lead-acid batteries. Journal of Power Sources, 191(1), 58-75.

Saravanan, M., Ganesan, M., \& Ambalavanan, S. (2012). A modified lead-acid negative electrode for high-rate partial-stateof-charge applications. Journal of The Electrochemical Society, 159(4), A452-A458.

Saravanan, M., Ganesan, M., \& Ambalavanan, S. (2015). Enhanced electrochemical performance of a lead-acid battery by a surface modified negative grid with multiwall carbon nanotube coating. $R S C$ Advances, 5(33), 26081-26091.

Shang, X., Chi, J.-Q., Lu, S.-S., Gou, J.-X., Dong, B., Li, X., Liu, Y.-R., Yan, K.-L., Chai, Y.M., \& Liu, C.-G. (2017). Carbon fiber cloth supported interwoven WS2 nanosplates with highly enhanced performances for supercapacitors. Applied Surface Science, 392, 708-714.

Shiomi, M., Funato, T., Nakamura, K., Takahashi, K., \& Tsubota, M. (1997). Effects of carbon in negative plates on cycle-life performance of valve-regulated lead/acid batteries. Journal of Power Sources, 64(1), 147-152.

Smith, T. A., Mars, J. P., \& Turner, G. A. (2002, 23-27 June 2002). Using supercapacitors to improve battery performance. Paper presented at the 2002 IEEE 33rd Annual IEEE Power Electronics Specialists Conference. Proceedings (Cat. No.02CH37289).

Soria, M. L., Hernández, J. C., Valenciano, J., Sánchez, A., \& Trinidad, F. (2005). New developments on valve-regulated lead-acid batteries for advanced automotive electrical systems. Journal of Power Sources, 144(2), 473-485.

Su, Y.-S., \& Manthiram, A. (2012). Lithiumsulphur batteries with a microporous carbon paper as a bifunctional interlayer. Nature Communications, 3(1), 1166.

Sugumaran, N., Everill, P., Swogger, S. W., \& Dubey, D. P. (2015). Lead acid battery performance and cycle life increased through addition of discrete carbon nanotubes to both electrodes. Journal of Power Sources, 279, 281-293.

Wang, G., Zhang, Y., Zhou, F., Sun, Z., Huang, F., Yu, Y., Chen, L., \& Pan, M. (2016). Simple and fast synthesis of polyaniline nanofibers/ carbon paper composites as supercapacitor electrodes. Journal of Energy Storage, 7, 99-103.

Xiang, J., Ding, P., Zhang, H., Wu, X., Chen, J., \& Yang, Y. (2013). Beneficial effects of activated carbon additives on the performance of negative lead-acid battery electrode for high-rate partial-state-ofcharge operation. Journal of Power Sources, 241, 150-158.

Yang, H., Qiu, Y., \& Guo, X. (2017). Lead oxide/ carbon black composites prepared with a new pyrolysis-pickling method and their effects on the high-rate partial-state-ofcharge performance of lead-acid batteries. Electrochimica Acta, 235, 409-421.

Yin, J., Lin, N., Zhang, W., Lin, Z., Zhang, Z., Wang, Y., Shi, J., Bao, J., \& Lin, H. (2018). Highly reversible lead-carbon battery anode with lead grafting on the carbon surface. Journal of Energy Chemistry, 27(6), 16741683.

Yin, J., Lin, N., Lin, Z., Wang, Y., Shi, J., Bao, J., Lin, H., \& Zhang, W. (2019). Optimized lead carbon composite for enhancing the performance of lead-carbon battery under HRPSoC operation. Journal of Electroanalytical Chemistry, 832, 266-274. 
Zhang, G., Sun, S., Yang, D., Dodelet, J.P., \& Sacher, E. (2008). The surface analytical characterization of carbon fibers functionalized by $\mathrm{H} 2 \mathrm{SO} 4 / \mathrm{HNO} 3$ treatment. Carbon, 46(2), 196-205.

Zhang, J., Yi, X.-b., Liu, S., Fan, H.-L., Ju, W., Wang, Q.-C., \& Ma, J. (2017). Vertically aligned carbon nanotubes/carbon fiber paper composite to support Pt nanoparticles for direct methanol fuel cell application. Journal of Physics and Chemistry of Solids, 102, 99-104.

Zhang, L. L., Gu, Y., \& Zhao, X. S. (2013). Advanced porous carbon electrodes for electrochemical capacitors. Journal of Materials Chemistry A, 1(33), 9395-9408.
Zhang, X., \& Shen, Z. (2002). Carbon fiber paper for fuel cell electrode. Fuel, 81(17), 2199-2201.

Zimáková, J., Vaculík, S., Bača, P., \& Fryda, D. (2015). The importance of observation of structural changes of lead acid battery active mass in special applications in the mining industry. Acta Montanistica Slovaca, 20, 165-171.

Zou, X., Kang, Z., Shu, D., Liao, Y., Gong, Y., He, C., Hao, J., \& Zhong, Y. (2015). Effects of carbon additives on the performance of negative electrode of lead-carbon battery. Electrochimica Acta, 151, 89-98. 